\title{
Wyrok Sądu Metropolitalnego w Katowicach (c. Sobański) z 16.9.2003 : o nowe wniesienie sprawy
}

Ius Matrimoniale 9 (15), 241-244

2004

Artykuł został zdigitalizowany i opracowany do udostępnienia w internecie przez Muzeum Historii Polski w ramach prac podejmowanych na rzecz zapewnienia otwartego, powszechnego i trwałego dostępu do polskiego dorobku naukowego i kulturalnego. Artykuł jest umieszczony w kolekcji cyfrowej bazhum.muzhp.pl, gromadzącej zawartość polskich czasopism humanistycznych i społecznych.

Tekst jest udostępniony do wykorzystania w ramach dozwolonego użytku. 
Ius Matrimoniale 9 (15) 2004

\section{Dekret Sądu Metropolitalnego w Katowicach (c. Sobański) $z$ 16.9.2003 (o nowe wniesienie sprawy)}

JK oraz AR zawarli małżeństwo 25.4.1981. Ważność tego małżeństwa zaskarżyła AR. Sprawę prowadzono z tytułu niezdolności z przyczyn natury psychicznej - powódki do podjęcia istotnych obowiązków małżeńskich. Wyrokiem z 30.12.1992 Trybunał orzekł, iż nie udowodniono nieważności małżeństwa. Wskutek apelacji pozwanego z 27.5.1995 sprawa znalazła się w II instancji. Na prośbę powódki z 10.6.1996 wprowadzono drugi jeszcze tytuł nieważności, mianowicie niezdolność pozwanego $-\mathrm{z}$ racji psychicznych - do podjęcia istotnych obowiązków małżeńskich. Wyrokiem z 14.1.1998 Sąd apelacyjny stwierdził, iż nie udowodniono nieważności małżeństwa z żadnego z rozpatrywanych tytułów. Przychylając się do prośby pozwanego Najwyższy Trybunał Sygnatury Apostolskiej reskryptem z 11.3.2003 powierzył Sądowi Metropolitalnemu w Katowicach: 1) decyzję - jeśli któraś ze stron o to wniesie - czy należy dopuścić nowe wniesienie sprawy zgodnie z kan. 1644 §1 z tytulu niezdolności powódki do podjęcia istotnych obowiązków małżeńskich, a w razie udzielenia odpowiedzi twierdzącej rozpatrzenie sprawy; 2) rozpatrzenie - jeśli któraś ze stron o to wniesie - jak w drugiej instancji sprawy z tytulu niezdolności pozwanego do podjęcia istotnych obowiązków małżeńskich. Akta sprawy nadeszły 30.5.2003. Dnia 2.6.2003 wyznaczono skład osobowy Sądu.

Powódka wniosła o zatwierdzenie wyroku II instancji. Z pozwanym dokonano wymiany korespondencji (pisma z 3.6; 11.7. i 8.8). Pozwoliła ona ustalić, że pozwany nie popiera sprawy z tytułu jego niezdolności do podjęcia istotnych obowiązków małżeńskich, domaga się natomiast rozpatrzenia jej $w$ trzeciej instancji $z$ tytułu takiejże niezdolności po stronie powódki. Ponieważ Sąd w terminie dłuższym niż 30-dniowym nie doczekał się przedstawienia przez pozwanego nowych, nierozpatrywanych dotychczas dowodów wzgl. argumentów, przystąpił do powzięcia decyzji w sprawie. 


\section{Stan prawny:}

Wszystkim „wiernym przysługuje legalne dochodzenie i obrona przysługujących im w Kościele uprawnień na właściwym forum kościelnym według przepisów prawa” (k. 221 §1). Do przysługujących uprawnień - wynikających $z$ naturalnych praw osoby - należy nie tylko prawo skargi, ale także prawo odwołania się od wyroku sądowego. Stąd dyspozycja k. 1628: „Strona, która czuje się pokrzywdzona jakimś wyrokiem”, ma „prawo apelować od wyroku do wyższego sędziego". Do wniesienia i poparcia apelacji wystarcza sama prośba o zmianę wyroku (k. 1634 §1), strona apelująca nie musi uzasadniać, dlaczego czuje się pokrzywdzona. Do prawa chroniącego prawa osoby należy jednak też zapewnienie pewności prawnej. Dlatego po dwóch zgodnych wyrokach "między tymi samymi stronami, co do tego samego żądania i z tego samego tytulu roszczenia" sprawy przechodzą w stan rzeczy osądzonej (k. 1641 n. 1). („Rzecz osądzona cieszy się prawomocnością i nie może być bezpośrednio podważana" - k. 1642 \$1, chyba że „wyraźnie wiadomo o jego niesprawie-dliwości" spowodowanej jedną z przyczyn wyliczonych w k. $1645 \$ 2$. Gdyby wykazano istnienie jednej z owych przyczyn, przysługuje prośba o przywrócenie do stanu poprzedniego - k. 1645 §1). Jednak sprawy o stan osób, a więc także sprawy o nieważność malżeństwa, nigdy nie przechodzą w stan rzeczy osądzonej (k. 1643). Racją tej normy jest dobro dusz, nakazujące wyczerpać wszystkie środki przydatne do wyświetlenia prawdy materialnej. Prawda materialna przeważa w takich sprawach nad racjami natury proceduralnej. Zachodzi przeto konieczność przyporządkowania zasady prawdy materialnej (równoznacznej w takich przypadkach z dobrem duchowym stron) oraz wymogu pewności prawnej (koniecznej ze względu na dobro publiczne, a ostatecznie także ze względu na dobro duchowe wiernych, któremu nie służyłoby nieuzasadnione przewlekanie procesów).

Stąd norma k. 1644 §1, wedle której można po dwu zgodnych wyrokach dotyczących stanu osób odwołać się do trybunału apelacyjnego przedstawiając - w zawitym terminie trzydziestu dni od wniesienia zaskarżenia - „,nowe i poważne dowody lub argumenty”. Chodzi o dowody, którymi strona zaskarżająca wyrok faktycznie dysponuje, a nie o takie, które mogą się wyłonić w trakcie instrukcji sprawy („debent in promptu esse" - sent. 13.7.1998 c. Defilippi - RRTDec. 90,2003,64). Dowody nowe to takie, które w ogóle nie były dotychczas przedstawio- 
ne wzgl. takie, których nie wykorzystano w aspekcie rozpatrywanej sprawy. Dowody są poważne, gdy mogą dostarczyć wiedzy o nieznanych dotąd faktach i - konsekwentnie - stanowić podstawę zmiany wyroku. W sprawach o nieważność malżeństwa nowe dowody to albo nieprzedłożone dotychczas dokumenty albo świadkowie, których nie można było odnaleźć wcześniej. Nowe i poważne argumenty to takie, które wykazują, że dotychczasowym, zgodnym wyrokom brak podstaw prawnych lub faktycznych. Nie mieści się w pojęciu nowych i poważnych argumentów polemika $z$ ustaleniami wyłożonymi w wyrokach ani krytyka wyroków czy sądów. Prawo odmawia sądowi kompetencji do przyjęcia sprawy do kolejnego rozpatrzenia, jeśli takich nowych i poważnych dowodów wzgl. argumentów nie przedłożono (sent. z 15.10.1998 c. Pompedda - RRTDec. 90,2003,606).

\section{Stan faktyczny:}

1. W prośbie z 18.9.2002 do Najwyższego Trybunału Sygnatury Apostolskiej pozwany pisze, że Trybunał II instancji, „zmarginalizowal znaczenie najważniejszego z dowodów”, „zbagatelizował dorobek i osiągnięcia psychologii rozwojowej” i dlatego on wnosi „o ponowne, pełne i dogłębne rozpatrzenie materiału dowodowego" oraz „o powołanie dodatkowego bieglego psychologa do oceny materiału dowodowego zgodnie z metodologią naukową psychologii klinicznej". Najwyższy Trybunał Sygnatury Apostolskiej pismem z 25.10.2002 zwrócił się do oficjała Sądu II instancji z zapytaniem, o co (konkretnie: o który tytuł nieważności) chodzi wnoszącemu prośbę. Dnia 20.1.2003 pozwany „potwierdził”, że chodzi mu o ponowne rozpatrzenie sprawy w III instancji z tytułu niedojrzałości psychicznej powódki, wnosząc zarazem, by do jej rozpatrzenia wyznaczono Sąd Diecezji (...). Powódka nie wyraziła zgody na ponowne rozpatrzenie sprawy. Najwyższy Trybunał Sygnatury Apostolskiej zdecydowal, jak to wyżej podano.

2. Ani powódka ani pozwany nie popiera rozpatrzenia $w$ trybie apelacyjnym sprawy $z$ tytułu niezdolności pozwanego do podjęcia istotnych obowiązków małżeńskich. Wobec braku apelacji od tej części wyroku Sąd nie może przyjąć sprawy do rozpatrzenia z tego tytułu.

3. Sąd zwrócil się do stron z odnośnymi pytaniami 3.6.2003. Pozwany nadesłał pismo $z$ datą 4.8.2003. Merytoryczna odpowiedź sprowadza się do następującego stwierdzenia: „Sąd obliguje mnie do przed- 
stawienia odnośnie p. 1 nowych, nie rozpatrywanych dotychczas dowodów, mimo że w piśmie do Najwyższego Trybunału Sygnatury Apostolskiej wniosłem jednoznacznie o ponowną analizę zgromadzonego materiału dowodowego, zobowiązując się do ewentualnej dodatkowej wypowiedzi na pytania Sądu i wnosząc o powołanie dodatkowego biegłego psychologa do oceny zgromadzonego materiału dowodowego odnośnie stopnia niedojrzałości psychicznej AR do zawarcia ważnego małżeństwa, bądź też przeprowadzenia dodatkowego jej badania o ile uzna za wskazane i niezbędne do wydania opinii potwierdzającej stwierdzenia biegłej. Nie twierdziłem, że przedstawię nowe dowody, ale te dowody mogą powstać i powstaną, jeżeli Sąd podejmie niezbędne działania, o które prosiłem".

Pozwany pisze, że jego wypowiedź oraz ocena biegłego, o którego powołanie wnosi, „będą wlaśnie nowymi dowodami w sprawie”. Na pismo, w którym Sąd usiłuje pozwanemu wyjaśnić prawne i proceduralne aspekty sprawy, pozwany nie zareagowal.

Skoto pozwany zeznawał w procesie, jego „wypowiedź” nie jest nowym dowodem. Powolanie biegłego należy do Sądu, stąd wniosek o powołanie dodatkowego biegłego nie może zostać uznany za nowy dowód. Pozwany domaga się ponownej analizy materiału dowodowego, ale nie przedłożył nowych dowodów wzgl. argumentów, które pozwolityby Sądowi przyjąć sprawę do rozpatrzenia i następnie dokonać analizy, o którą wnosi pozwany. Po dwu zgodnych wyrokach samo żądanie ponownej analizy materiału dowodowego nie daje podstaw do dopuszczenia sprawy do kolejnego rozpatrzenia.

Niestety, pismo pozwanego z 4.8.2003 trzeba rozumieć jako wyraźną odmowę przedłożenia nowych dowodów. Wobec takiego stanu sprawy Sąd nie może przyjąc sprawy do nowego rozpatrzenia z tytułu niezdolności powódki do podjęcia istotnych obowiązków małżeńskich.

Tak więc Sąd postanawia:

Wobec braku nowych i poważnych dowodów wzgl. argumentów Sąd nie dopuszcza sprawy do kolejnego rozpatrzenia z tytułu niezdolności powódki do podjęcia istotnych obowiązków małzeńskich;

Wobec braku apelacji Sąd nie przyjmuje sprawy do rozpatrzenia na stopniu apelacyjnym $-z$ tytułu niezdolności pozwanego do podjęcia istotnych obowiązków małżeńskich. 